\title{
RAN wt Allele
}

National Cancer Institute

\section{Source}

National Cancer Institute. RAN wt Allele. NCI Thesaurus. Code C134695.

Human RAN wild-type allele is located in the vicinity of 12 q24.33 and is approximately 6 $\mathrm{kb}$ in length. This allele, which encodes GT P-binding nuclear protein Ran, plays a role in nuclear import and export of proteins and RNAs. 